\title{
A prospective study of demographic and socioeconomic factors responsible for non-acceptance of family planning methods at tertiary care teaching hospital, Gujarat, India
}

\author{
Neelam Joharwal*, Shital Kapadia
}

Department of Obstetrics and Gynecology, B.J. Medical College, Civil Hospital, Ahmedabad, Gujarat, India

Received: 08 May 2021

Revised: 06 August 2021

Accepted: 07 August 2021

\section{*Correspondence:}

Dr. Neelam Joharwal,

E-mail: neelamjoharwa192@gmail.com

Copyright: () the author(s), publisher and licensee Medip Academy. This is an open-access article distributed under the terms of the Creative Commons Attribution Non-Commercial License, which permits unrestricted non-commercial use, distribution, and reproduction in any medium, provided the original work is properly cited.

\begin{abstract}
Background: Population explosion has been major challenge for India since Independence. The adoption of contraceptive methods remains the best solution to this problem. The objective of this study was to determine the factors for non-acceptance of different contraceptive methods among married women of postnatal ward in tertiary care hospital, Ahmedabad, Gujarat, India. The aim of the study was to analyse about the level of awareness and attitude towards different methods of contraception among married women of reproductive age groups.

Methods: It was a prospective observational study carried out in the department of obstetrics and gynaecology, B. J. Medical College, Civil Hospital, Ahmedabad, Gujarat, India, a tertiary care teaching hospital from June 2019 to November 2020. 200 patients meeting inclusion criteria were included. Case sheets were analysed to obtain data regarding reasons for non-acceptance of contraceptive methods.

Results: In our study, we found that among study population $64 \%$ women use family planning methods, which was still low as compared to developed countries. $36 \%$ women were non-users in study population. The main reason of nonacceptance of contraceptive method were desire for male child, non-allowance by religion/custom, the myth regarding price of contraceptive method, desire of more children and worry about side effects.

Conclusions: To increase the use of contraceptive among women, we can increase awareness about different family planning method with counselling about various available contraceptives. It is also important to increase participation of husbands as they often influence the decision regarding reproductive health of women.
\end{abstract}

Keywords: Contraceptive methods, Reproductive health, Non-acceptance

\section{INTRODUCTION}

Since independence, population explosion remains the major problem of the India. This is the major hurdle in the overall progress of the country. Family planning method adoption is one of the best solutions to tackle this problem. 'India was the first country to adopt an official population policy and launch official family planning program in 1952. This program remains the keystone of all family planning programs. It was only after 1971 population census, the family planning as a strategy received due attention'. 'Only $54 \%$ of eligible couples were using a contraceptive method in 2007-08 to control their fertility', and 'the contraceptive prevalence appears to have become stagnant after 2004'.,3 As per National Family Health Survey (NFHS-4) results, current use of any of the family planning methods has dropped to $53.5 \%$ in comparison to $56.3 \%$ reported by NFHS-3.,5

Further, contraceptive practice in India is heavily skewed towards terminal methods which reveal that birth limitation is the primary aim of contraception rather than 
birth planning. The current population of India is $1,380,004,385$ with a decadal growth of $17.70 \%$, while the fertility rate is 2.24 births per woman. It suggests that population in India will be 150 crores by the year 2031 . Such a population will strain our resources and create a hurdle in the growth of the country as land and natural resources are not going to increase as compared to the population. The solution to this population explosion is family planning, rapid economic development, and appropriate social transformation. The sooner this transformation occurs, the closer mankind will be to the solution of the problems of poverty and overpopulation.

\section{Aim and objective}

The aim of the study was to analyze about the level of awareness and attitude towards different methods of contraception among married women of reproductive age groups.

\section{METHODS}

It was a prospective observational study carried out in the department of obstetrics and gynaecology, B. J. Medical College, Civil Hospital, Ahmedabad, Gujarat, India after approval from Indian Ethics Committee.

\section{Selection criteria}

\section{Inclusion criteria}

Patients with following criteria were included- (a) married women of postnatal ward, who were delivered at Civil Hospital, Ahmedabad; (b) women between age of 18-45 years of age, who are willing to participate in the study and ready to give consent; (c) couple should have at least 1 live child; and (d) mentally sound patient, so that she can understand the methodology.

\section{Exclusion criteria}

Patient with following criteria were excluded- (a) not willing to participate in the study; (b) women with psychiatric illness; and (c) women with medical illness like congenital heart disease, uncontrolled diabetes mellitus, septicemia or any surgical illness.

\section{Study protocol}

Proposed study was conducted in the department of obstetrics and gynecology at Civil Hospital, Ahmedabad. The duration period of this study will was1 year and 6 months months. Study of 200 postnatal women was conducted during the specified period. 200 post-natal mothers were enrolled in this study randomly according to inclusion criteria after informed consent. A detailed history of all enrolled patients was taken and noted in specially designed proforma. We have studied relationship of following parameters with contraception use in our study: (1) age; (2) socio-economic status; (3) education status of woman and spouse; (4) occupation; (5) type of family; (6) religion; (7) registration status of woman; and (8) number of live male child.

History including type of delivery, delivery outcome, obstetric history, past medical history, family history, personal history and previous contraceptive history was taken.

\section{Outcomes}

The outcomes of interest included: relationship between different demographic factors and use of contraception prevalence. knowledge of contraceptive methods among study population, types of contraceptives used by women, reasons for non-acceptance of contraceptive methods among non-users.

\section{Statistical analysis}

Data were collected and analyzed. Chi square test was performed and $p$ value was derived. Data entry was done in Microsoft excel and analysis was done using a software Epi Info 7.

\section{RESULTS}

Maximum number of women, who were using contraceptives (25\%) were in 20-24 years of age group. As we can see, among women, who were graduate, $78.26 \%$ women or who had completed their higher secondary education, $82.35 \%$ women opted for contraception more often as compared to less educated. Among women studied till primary or middle school, $58.40 \%$ and among illiterate women, $8 \%$ were using contraception. As can be seen, out of husbands of 128 women, who were contraceptive users, no husband was illiterate, 16 husbands $(12.5 \%)$ were educated upto primary school, 28 husbands $(21.87 \%)$ were educated upto middle school, 54 patients $(42.18 \%)$ were educated till high school and 20 patients $(15.62 \%)$ had completed their graduation.

Percentage of Hindu women accepting contraceptive methods was higher $(61.82 \%)$ as compared to Muslims $(9.09 \%)$. There was only one Christian in our study group. Because of this small number, it is difficult to interpret the data. In this study, the percentage of users among poor women was only $10.71 \%$, among women of lower middleclass women, the use of contraceptive method was about $69.56 \%$ and in women of upper class or upper middle class, prevalence of contraceptive use was $87.02 \%$.

In our study, it has been seen that among women living in nuclear families, the use of contraceptives was $76.30 \%$, whereas among women living in joint families, the acceptance of contraceptive methods was $42.46 \%$.

In our study, patients were from urban areas out of which $71.2 \%$ women were using family planning methods and among women living in rural areas, $27.77 \%$ were using 
contraceptive methods. It can be observed from this study, that the acceptance of contraception is more in women having live male child. In our study, among number of women having no live male child, the acceptance of family planning method was $49.39 \%$, among women having 1 live male child it was $81.65 \%$ and among women having 2 or more live male children the acceptance of any contraceptive method was $87.5 \%$. Among booked patients, the percentage of contraceptive users was $67.53 \%$ as compared to $52.17 \%$ in un-booked patients. In our study, it is observed that among study population, the knowledge of at least one method of contraception was $91 \%$. During the study, the reasons for non-acceptance of contraceptives were asked. The main reasons for non-acceptance of family planning methods was their thinking that contraceptives were expensive $(29.17 \%)$ followed by nonallowance by different religion and customs (15.28\%). Desire of child, worry about side effects of contraceptives and desire of male child accounted for $12.50 \%, 11.11 \%$ and $11.11 \%$ respectively. Fear of surgery, thinking that occasional intercourse would not lead to pregnancy accounted for $9.72 \%$ and $8.33 \%$ respectively. About $2.78 \%$ of women did not have any valid reason for refusal for non-acceptance of contraceptive methods.

Table 1: Distribution of study patients according to demographic factors.

\begin{tabular}{|c|c|c|c|}
\hline Variables & Users & Non-users & P value \\
\hline \multicolumn{3}{|l|}{ Age (years) } & \multirow{6}{*}{0.5859} \\
\hline$<20$ & 8 & 5 & \\
\hline $20-24$ & 50 & 30 & \\
\hline $25-29$ & 37 & 20 & \\
\hline $30-34$ & 25 & 9 & \\
\hline$>35$ & 8 & 8 & \\
\hline \multicolumn{3}{|c|}{ Educational status of woman } & \multirow{6}{*}{0.00001} \\
\hline Illiterate & 2 & 23 & \\
\hline Primary school & 36 & 22 & \\
\hline Secondary school & 30 & 13 & \\
\hline Higher secondary school & 42 & 9 & \\
\hline Graduate & 18 & 5 & \\
\hline \multicolumn{3}{|c|}{ Educational status of husband } & \multirow{6}{*}{0.00001} \\
\hline Illiterate & 1 & 10 & \\
\hline Primary school & 15 & 30 & \\
\hline Secondary school & 38 & 16 & \\
\hline Higher secondary school & 54 & 11 & \\
\hline Graduate & 20 & 5 & \\
\hline Variables & Users & Non-users & \multirow{5}{*}{0.0006} \\
\hline \multicolumn{3}{|l|}{ Religion } & \\
\hline Hindu & 125 & 61 & \\
\hline Muslim & 1 & 11 & \\
\hline Others & 2 & 0 & \\
\hline \multicolumn{3}{|l|}{ Socioeconomic status } & \multirow{5}{*}{0.00001} \\
\hline Poor & 3 & 28 & \\
\hline Lower middle & 96 & 42 & \\
\hline Upper middle/upper & 27 & 2 & \\
\hline Total & 128 & 72 & \\
\hline \multicolumn{3}{|l|}{ Type of family } & \multirow{3}{*}{0.00001} \\
\hline Nuclear & 97 & 30 & \\
\hline Joint & 31 & 42 & \\
\hline \multicolumn{3}{|l|}{ Residence } & \multirow{3}{*}{0.00001} \\
\hline Rural & 10 & 26 & \\
\hline Urban & 118 & 46 & \\
\hline \multicolumn{3}{|l|}{ Registration status } & \multirow{3}{*}{0.568} \\
\hline Booked & 104 & 50 & \\
\hline Un-booked & 24 & 22 & \\
\hline \multicolumn{3}{|l|}{ Number of live son } & \multirow{5}{*}{0.0007} \\
\hline 0 & 41 & 42 & \\
\hline 1 & 80 & 29 & \\
\hline 2 or more & 7 & 1 & \\
\hline 0 & 41 & 42 & \\
\hline
\end{tabular}


Table 2: Knowledge of contraception usage among women in study group.

\begin{tabular}{|lll|}
\hline Contraceptive knowledge & Number & Percentage $(\%)$ \\
\hline Yes & 182 & 91 \\
\hline No & 18 & 09 \\
\hline
\end{tabular}

Table 3: Details of reasons for non-acceptance of contraceptive methods among non-acceptors ( $N=72)$.

\begin{tabular}{|c|c|c|}
\hline Reasons & Number & Percentage $(\%)$ \\
\hline Think that contraceptives are expensive & 9 & 12.50 \\
\hline Desire of male child & 21 & 29.17 \\
\hline Religion/customs don't allow & 11 & 15.28 \\
\hline Worried about side effects & 8 & 11.11 \\
\hline Fear of surgery (TL) & 7 & 9.72 \\
\hline Think that occasional sex would not lead to pregnancy & 6 & 8.33 \\
\hline Want more children & 8 & 11.11 \\
\hline
\end{tabular}

\section{DISCUSSION}

In our study, no significant association was found between age group of women and contraceptive acceptance. Mean age+/-standard deviation is $26.08 \pm 5.31$. As the level of literacy increases, the number of patients who accepted some method of contraception increases. The contraceptive prevalence rate differs significantly with literacy status of the wife $(\mathrm{p}<0.00001)$. These results were well supported by Manna et al, Sharma et al, Shobha et al, Gupta et al and Anil et al..$^{6-10}$

Education status of husband is also important. Educated husbands can understand and support their decision of using contraceptives. In the present study, there was significant association between literacy status of husband and usage of contraceptives $(\mathrm{p}<0.00001)$. This result were similar to studies by Manna et al, Sharma et al, Shobha et al, Gupta et al and Anil et al. ${ }^{6-10}$ It can be observed that percentage of women accepting family planning methods is higher in Hindus as compared to Muslims. It may be because of their rituals or customs which are against using family planning methods. In this study, a significant association was found between religion and acceptance of contraceptive use $(\mathrm{p}<0.05)$.

Socio-economic factors influence both choice and use of contraception. There is evidence that low socioeconomic status women are less likely to use contraception overall. In the present study, a significant association was found between socio-economic status of the patient and the use of contraceptives $(p<0.00001)$. The findings of the current study was different from those reported by Gupta et al, Manna et al, and Haldar et al. ${ }^{6,9,11}$

In this study, more prevalence of contraceptive among nuclear family suggests the influence of other family members in terms of use of contraceptive method among young couples. A higher proportion of contraceptive receptors belonged to nuclear families $(\mathrm{p}<0.00001)$. These findings were similar to those reported by Bisoi et al, Haldar et al, and Gupta et al., ${ }^{911,12}$ In this study, a significant association was found between well-developed residence areas and contraceptive use $(\mathrm{p}<0.00001)$.

In our study, there was no significant association between registration status of women and contraceptive status ( $>0.05$ ). In our study, there was significant relationship was found between the number of surviving male child and contraceptive acceptance (0.0007). This result was similar to studies by Rangamuthia et al, Rama et al, Das et al, Patro et al, Murarkar et al and Ghosh et al. ${ }^{13-18}$

The results show that $91 \%$ women of study group have knowledge regarding at least one family planning method. Women with no formal education of lower education levels have less access to family planning information through any mass media than those with higher education. As it can be seen that the knowledge about the contraceptive methods is not reflected in their actual acceptance.

During the study, the main reasons for non-acceptance of contraceptives were ask their thinking that contraceptives were expensive, followed by non-allowance by different religion and customs. Desire of child, worry about side effects of contraceptives and desire of male child were next common reasons. Fear of surgery, thinking that occasional intercourse would not lead to pregnancy accounted for other reasons for non-acceptance of contraceptives.

\section{CONCLUSION}

Population explosion is a big challenge for India. The impact of overpopulation is disastrous for the present as well as future generations as a rise in population is resulting in depletion of the resources, degradation of the environment and unemployment. In our study, we found that among study population $64 \%$ women use family planning methods, which is still low as compared to developed countries. $36 \%$ women were non-users in study population. The main reason of non-acceptance of contraceptive method were desire for male child, non allowence by religion/custom, the myth regarding price of 
contraceptive method, desire of more children and worry about side effects. In our study, we have seen that due to our patriarchal society, most of the women are not given authority of taking decision regarding choosing family planning methods and also many other matters of family. This is also related to knowledge and literacy level of society, which needs to be improved. To increase the use of contraceptive among families, we can increase awareness about different family planning method with counseling about various available contraceptives. This counseling should be started during antenatal period itself, when patients come for routine antenatal care. As an obstretician it's our duty to widen their knowledge regarding various contraceptive options and suggesting best suitable method for particular patient.

\section{Funding: No funding sources}

Conflict of interest: None declared

Ethical approval: The study was approved by the Institutional Ethics Committee

\section{REFERENCES}

1. Chaurasia AR, Gulati SC. India: The State of Population 2007. New Delhi, India: National Population Commission and Oxford University Press; 2008.

2. International Institute for Population Sciences. District Level Household and Facility Survey 2007-08, 2010. Available at: http://rchiips.org/pdf/indiareportdlhs-3.pdf. Accessed on 01 May 2021.

3. United Nations. World Contraceptive Patterns, 2013. Available at: https://www.un.org/en/development/desa/populatiop ublications/pdf/family/worldContraceptivePatternsW allChart2013.pdf. Accessed on 01 May 2021.

4. Ministry of Health and Family Welfare. National Family Health Survey (NFHS-4) 2015-16, 2018. Available at: http://rchiips.org/nfhs/nfhs4Reports/India.pdf. Accessed on 01 May 2021.

5. Ministry of Health and Family Welfare. National Family Health Survey (NFHS-3), 2017. Available at: http://www.rchiips.org/nfhs/NFHS3\%20Data/VOL1/ India_volume_I_corrected17oct08.pdf. Accessed on 01 May 2021.

6. Manna N, Basu G. Contraceptive methods in rural area of West Bengal, India. Sudanese J Public Health. 2011;6:164-9.

7. Sharma AK, Grover V, Agrawal OP, Dubey KK, Sharma S. Patterns of contraceptive use by residents of a village in South Delhi. Indian J Public Health. 1997;41:75-8.

8. Shobha J. Fertility and child survival: A study of selected slums of Hyderabad. Indian J Soc Work. 1990;1:134-40.

9. Gupta A, Roy TK, Sarker G, Banerjee B, Ghosh S, Pal R. Determinants of contraceptive practices among eligible couples of urban slum in Bankura District, west Bengal. J Family Med Prime Care. 2014;3(4):388-92.

10. Anil AP. Knowledge and practices of contraception among married females of rural Tamil Nadu. Asian J Biomed Pharm Sci. 2015;5(42):1-4.

11. Haldar A, Baur B, Mishra R, Dasgupta U, Banerjee L. Contraceptive practice: An experience from rural West Bengal, India. Int J Basic Appl Med Sci. 2012;2:174-8.

12. Bisoi S, Haldar A, Baur B, Mishra R, Dasgupta U, Banerjee L. Contraceptive practice: An experience from rural West Bengal, India. Int J Basic Appl Med Sci. 2012;2:174-8

13. Rangamuthia M, Kim CM, Fred A, Roy TK. Son Preference and Its effects on Fertility in India. National Family Health Survey Subject Reports. Number 3, 1997. Available at: http://rchiips.org/nfhs/research1.html. Accessed on 01 May 2021.

14. Rama R, Ghosh MN, Bhattacharya S. Study of unmet need for family planning among married women of reproductive age attending immunization clinic in a medical college of Calcutta. Indian J Community Med. 2000;25910:22-5.

15. Das R, Amir A, Nath P. Utilisation and coverage of services by women of Jawan Block in Aligarh. Indian J Comm Med. 2001;26(2):92-100.

16. Patro BK, Kant S, Baridalyne N, Goswamy AK. Contraceptive Practice among married women in a resettlement colony of Delhi. Health Pop Perspec Iss. 2005;28(1):9-16.

17. Murarkar SK, Soundale SG. Epidemiological correlates of contraceptive prevalence in married women of reproductive age group in rural area. Natl $\mathbf{J}$ Community Med. 2011;2(1):78-81.

18. Ghosh S, Samanta A, Mukherjee S. Knowledge and practice of family planning in married women of reproductive age group in a slum of Kolkata. Al Ameen J Med Sci. 2013;6(1):34-9.

Cite this article as: Joharwal N, Kapadia S. A prospective study of demographic and socioeconomic factors responsible for non-acceptance of family planning methods at tertiary care teaching hospital, Gujarat, India. Int J Reprod Contracept Obstet Gynecol 2021;10:3361-5. 